SOSYAL POLITIKA CALISMALARI DERGISI

\title{
İNFORMAL ÖĞRENME, ÇOCUK VE SUÇ OLGUSU
}

İbrahim E. BİLİCí ${ }^{1}$

\section{Öz}

Öğrenme anne karnında başlayıp aile başta olmak üzere, sosyal çevre içinde informal öğrenme ile hayat boyu devam etmektedir. Formal eğitim süreçlerini aşan informal öğrenme ortamları, bir taraftan istendik davranıșları, öte yandan suç niteliğindeki eylemler de dâhil olmak üzere, neyi örnek gösterir, nasıl bir model oluşturursa o, çocuğu etkilemektedir. Çocuk gelişiminde çocuğun ilgi, sevgi, şefkat ve güven gibi temel ihtiyaçlarının aile tarafından yeterince karşılaması veya çocuğa kayıtsız kalmasıyla; informal öğrenme ortamlarının yönlendirmesiyle kimlik, kişilik, karakter ve değerler inşa edilmektedir. Örgün (formal) eğitime güçlü bir alternatif hatta tehdit konumundaki medya ile yapılan informal öğrenme, öğrenme çağındaki çocuklarda çok etkili olmakta, kimi zaman informal öğrenme örgün eğitime baskın çıkmaktadır.

Nitel literatür incelemesine dayanan ve derleme makale niteliği taşıyan bu betimsel çalışmanın amacı; hızla ilerleyen dijital iletişim teknolojilerinin çocuklar üzerindeki muhtemel ve muhtelif eğitici etkilerini belirtmek, istenmeyen davranışların ortaya çıkış neden ve sonuçlarını nedensellik bağı içinde tespit etmek, suç olgusu başta olmak üzere, ilgili güncel sorunların çözümüne katkıda bulunabilecek öneriler sunmaktır.

Anahtar Kelimeler: Çocuk, informal öğrenme, medyadan öğrenme, medyadan suç taklidi, medya okuryazarlığı.

Yrd. Doç. Dr. Erciyes Üniversitesi İletişim Fakültesi. ibilici@yandex.com.tr 
Abstract

Learning starts in the main abdominal and continues for a lifetime in the form of informal learning in a primarily family and social environment. Whatever informal learning environments which surpass formal education processes exemplify, incentivize and model as desired behaviors on the one hand and criminal activities on the other has an influence on the child. In child development, identity, personality, character, and values are constructed as a result of the fulfillment of the child's basic needs such as care, affection, compassion and trust by the family or being inattentive towards them and the encouragement from informal learning environments. Informal learning via media, which is a powerful and even threatening alternative to formal education is very effective on children at the learning age, sometimes informal learning predominates over formal education.

Objective of this descriptive research based on qualitative literature review is to identify the probable and diverse effects of the ever-developing digital technologies on children, to investigate why undesirable behaviors emerge and the related issues by emphasizing the causal relations and to offer suggestions that can contribute to the solution of the current related problems, primarily the crime phenomenon.

Keywords: Child, informal learning, learning from media, copycat crime, media literacy. 


\section{Giriș}

Sosyal bir varlık olarak toplum içinde yaşayan insanın, beşikten mezara devam eden öğrenme süreçlerinde, iyi ve kötü davranışlar öncelikle aileden öğrenilmektedir. Çocuklukta temeli atılan, başat informal ${ }^{1}$ öğrenme araçları olarak medya ve sosyal çevreyle genişleyen ve örgün eğitim ile belirli bir sistematiğe giren öğrenme, insanı biçimlendirmekte ve 'nasıl' bir insan olduğunu belirlemektedir.

Suç ile sonuçlanan davranışlarda bu öğrenme süreçlerinin, psikolojik ve sosyolojik gelişimin, medyanın başat rolü bulunmaktadır (Şirin, 2011, s. 167). Hırsızlık, terör faaliyetleri, cinsel istismar, siber suçlar, kötü alışkanlık ve bağımlılıklar gibi istenmeyen davranışlar öğrenme ve sosyal etkileşimle yakından ilişkilidir. Suçun önlenmesi için öncelikle suça neden olan sebeplerin mümkün olduğunca ortadan kaldırılması gerekmektedir.

\section{Yöntem}

$\mathrm{Bu}$ araştırmada, örgün eğitimin dışında yer alan medya ve diğer öğrenme kaynaklarından öğrenilenler, suç olgusunun sebepleri, ortaya çıkan sorunlar, sorumluluklar, çözüm önerileri hiyerarşisinde bir çerçeve oluşturmak üzere makro ölçekte, öğrenme, çocuk ve suç olgusu incelenmiştir. Kültürel değerler zemininde, nedensellik bağı üzerine kurulu olarak sorun, sebep, öneriler ve sonuç uzamında geniş bir çerçeve oluşturmak üzere yapılan bu betimsel çalışma, nicel literatür incelemesine dayanmaktadır.

Araştırmanın amacı; hızla ilerleyen dijital iletişim teknolojilerinin, aile ve sosyal çevrenin çocuklar üzerindeki muhtemel ve muhtelif etkileri, istenmeyen davranışların ortaya çıkış nedenlerini tespit etmek, sebep-sonuç ilişkisi içinde çocuk, öğrenme ve suç olgusunu incelemek ve suç olgusu başta olmak üzere, ilgili güncel sorunların çözümüne katkıda bulunabilecek öneriler sunmaktır.

\footnotetext{
${ }_{1}^{1}$ Türk Dil Kurumu çevrimiçi sözlüğünde, İngilizce formal sözcüğüne karşılık olarak biçimsel, resmi; informal sözcüğü için de zıttı verilmektedir. Ancak informal öğrenme bağlamında kullanıldığında bu sözcüğün amaçlanan anlamı tam olarak karşılamadığı görülmektedir. Formalite sözcüğünde olduğunun aksine, informel yazıldığında da (normel, kamusel, kişisel dendiğindeki gibi) sesletimi alışılanın dışında kalacaktır. Bu sebeplerle, neden bahsedildiğini tam belirtebilmek için bu araştırmada sözcüğün doğrudan İngilizce'den geçen hali kullanılıp informal yazılmıştır.
} 
Çocuk suçluluğunun genel olarak nedenleri biyolojik (kalıtımsal), psikolojik ve sosyolojik olmak üzere üç temel alanda incelenmektedir (İçli, 2009, s. 22). Bu araştırmada çocuk ve suçu öğrenme açısından özellikle birey ve psikolojik zemin üzerinde durulmaktadır. Araştırmada 1-17 yaş aralığındaki bireyler 'çocuk' olarak kabul edilmiş, öncelikle psikolojik zeminde bir birey olarak çocuk incelenmiş, çocukluktan itibaren informal öğrenme ortamı olan medya ve sosyal çevre incelenmiştir. Sosyolojik zeminde de toplum içinde çocuk gelişiminin ana hatları çizilmiştir.

$\mathrm{Bu}$ araştırmada atasözlerinden de yararlanılmıştır. İçerik olarak felsefi derinlik, estetik duygu ve fikir yoğunluğu barındıran dil olarak uyaklı, kafiyeli olup hatırda kalan, temsil ettiği coğrafyaların çeşitli konulardaki görüş ve düşüncelerini, değer yargılarını yansıtan atasözleri, bir toplumun kültürünün aynasıdır (Ercan, 2014, s. 16). Bu özellikleriyle çocuklarla ilgili atasözleri, ilk defa çocuk yetiştiren ebeveynler için önemli bir yol göstericidir.

\section{Sorun}

Toplumun en temel yapı taşını oluşturan ailenin korunamaması ve ailelerdeki parçalanmalar en fazla çocukları etkilemektedir. Çeşitli sosyal sorunlar toplumun önemli bir parçası olan çocukları hem olumsuz eylemlere itmekte hem de çaresizliğe sürüklemektedir. Boşanma oranlarının arttı̆̆ı, aile kurumunun çözülmeye başladığı toplumlarda, hatta gelişmiş ülkelerde, aile kurumunun zayıflaması ile suç oranının aynı oranda arttığı görülmektedir (Gültekin, 2013, s. 6).

Türkiye İstatistik Kurumu verileri incelendiğinde, ülkemizde suça karışan çocuk sayısının her geçen gün arttığı görülmektedir. Türkiye'de 2009 yılından 2013 yılına kadar beş yıl içinde suça bulaşıp ceza infaz kurumuna giren 12-17 yaş arası hükümlü çocukların sayısı 1087'den 6132'ye çıkmıştır (TÜİK, 2014, s. 111). Beş yılda \%500'den fazla artış gösteren bu tehdit karşısında acil tedbir alınması gerekmektedir.

Şiddet içeren veya şiddete sürükleyen pek çok dış faktör, bireyde suç olgusu ile sonuçlanmaktadır. Doğru yetiştirildiğinde prososyal davranışlar sergileyebilecek bir çocuk, sürekli şiddete maruz kaldığında, kendisine 
çevresine karşı duyarsızlaşmaya başlamakta, agresif davranışlara yönelmekte hatta ilerleyen yaşlarda sosyopati vb. anormalliklerle toplum içinde bir tehdit olarak yer almaktadır. Diğer taraftan, toplumda şiddete maruz kalana karşı empati kurma gereksinimi duymama, suça karşı duyarsızlaşma, mağduru ve şiddeti sıradan ve olağan görme eğilimi ağır basmaktadır (Yavuzer, 1994, s. 44).

Medyada şiddet ise başlı başına bir sorundur. Gerbner gibi alandaki belli başlı otoritelerin çalışmalarıyla birlikte, alandaki üç bini aşkın araştırmanın bulgularına göre medyadaki yoğun şiddet içeriğinin bireyleri olumsuz etkilediği, şiddet ortamında yetişen, ailede ve toplumda şiddet ile büyüyen çocukların şiddeti daha çok kanıksadığı görülmektedir (Şirin, 2011, s. 168). Medyada şiddetin, bireylerin şiddete kurban gitme endişesi ve şiddete bulaşma korkusu yaşamasına neden olduğu da tespit edilmiştir (Callanan, 2005, ss. 1353).

Geleneksel medyadaki şiddet sürerken, ona bir de dijital medya (akıllı telefon, bilgisayar oyunları, sosyal medya ve benzeri dijital mecralar) eklenmiş, medya çocukları kuşatma altına almıştır. Örneğin şiddet içeren bilgisayar oyunları sadece bir eğlence midir? Öldürerek, yakıp yıkarak eğlence olabilir mi? Bu soruların üzerine Albert Bandura, Bobo Doll adlı deneyinde birtakım soru işaretleri inşa etmektedir. Bu deneyde çocuğun öfkesi hacı yatmaza yönlendirilir ve deşarj olma durumu gözlemlenir. Bu öfkeyi söndürmeye yarayan iyi bir araç mı, yoksa öfkelenmenin ne kadar sık olursa olsun olağan bir davranış olarak bir yerlere yönlendireceğini öğreten bir araç mıdır? Oyun bile olsa, en fazla sayıda insanı öldüren ödüllendirilebilir mi, ödüllendirilen davranışlar pekiştirilmez mi? $\mathrm{Bu}$ ve benzeri yığınla soru işareti, adeta birer paradoks oluşturmaktadır. Ancak görülen odur ki, özellikle şiddetin ödüllendirildiği durumda, medya veya sosyal çevresinden fiziksel şiddet gören çocuk, bundan etkilenip kendisi de aynı davranışı sergileme eğilimi göstermektedir (Bilici, 2014, ss. 55-56; Marsh ve Melville, 2009, s. 19).

Çocuk-medya-şiddet konusu üzerinde yoğunlaşan ve şiddet oyunlarının çocuğu şiddete yönlendirdiğini veya deşarj ettiğini veya aksine hiçbir etkisinin olmadığını bulan araştırmaları bilimsel kriterlere göre tasnif edip 
değerlendiren Bushman, Gollwitzer, ve Cruz’un (2015) bulgularına göre, her ne kadar bazı araştırmacılar bu konunun 'tartışmalı' olduğunu iddia etse de apaçık gerçek şudur: Medyadaki şiddet, çocukları da şiddete yönlendirmekte, her hâlükârda çocukları olumsuz etkilemektedir. Bu sonuca varan bilimsel araştırmalar, oyun üretici firmalar tarafından, ebeveyni boşuna telaşlandıran 'bostan korkuluğu' ve 'doğruluğu belirsiz şeyler' olarak lanse edilmekte, diğer medya endüstrileri de medyadaki şiddet ile çocuğun saldırgan davranışı arasındaki bağlantının belirsiz kalmasını istemekte, buna bazı araştırmacılar da katılmakta ve ağırlıklı olarak bu yönde propaganda yapılmaktadır (ss. 1-4, s. 8).

Amerikan Pediatri Akademisi bu konuda daha esnek açıklama yapmaktadır: Şiddet içeren medya içeriğine maruz kalmak ciddi bir sağlık riski ile karşı karşıya kalmaya neden olabilir. Öte yandan çocuk gelişimi ile ilgilenen araştırmacılar medya araştırmacılarından daha ciddi ve güçlü ses vermektedir. Ancak çocuklarının medyadan olumsuz etkilenmeleriyle ilgili ebeveynlerin düşüncelerinin ne olduğu -çocuklarıyla birlikte yaşayıp onları daha çok gözleme imkânlarının olmasına rağmen-yeterince bilinmemektedir (Bushman vd., 2015, s. 3). Çocuk üzerinde çok yönlü etkileriyle bilgisayar oyunlarında çözünürlük ve grafik kalitesi arttıkça, üç boyutlu ekranlar ile imajlar günden güne daha gerçekçi görünmektedir. Bu da gelişim çağında gerçeklik algısını bozmakta, çocuk üzerindeki olumsuz etki çok yönlü olmaktadır.

Roman olarak başlayıp, çizgi roman olarak devam eden, daha sonra da 2012 yılında ABD'de (ardından da dünyanın birçok yerinde) izlenme rekorları kuran (Hibberd, 2012) bir televizyon dizisi olarak gösterime giren, The Walking Dead $^{2}$ adlı dizi; Türkiyede çocuklar arasında popülaritesini 2015 yılında da korumuştur. Dizinin oyun versiyonunu, sadece liseliler değil ortaokul seviyesindeki çocuklar da internet üzerinden oynamaya başlamıştır. Hem diziyi takip eden, hem de oyununu oynayan çocuklar, oyun içinde diğerleriyle yardımlaşarak adeta senaryonun içine katılmaktadır.

\footnotetext{
2 Yürüyen Ölüler dizisinin ülkelere özel hazırlanmış internet sayfaları da bulunmaktadır. Türkiye için http://walkingdeadturkiye. com adresinin Türkçesi, 'yürüyen ölü Türkiye' karşılığıyla semiyolojik olarak negatif bir çağrışım (ironik olarak, Hasta adam artık yürüyen ölü mü oldu?) oluşturmaktadır. Merkez ülkelerde ülke isminin önüne yürüyen ölü gelmiş mi diye; uk, gb, au, gibi ülke kısaltmalarıyla internet sayfaları araştııımış, bu ülke adlarının önünde yürüyen ölüye rastlanmamıştır.
} 
Medya, hayat yolculuğunda çocukları mücadelecilik ruhu yerine mücadeleden kaçışa, hazcılığa, hazırcıllı̆a ve tembelliğe yönlendirmektedir. Medyada parlak-şahane yaşantıları gören ve imrenen çocuğa; ömür-boyu çalışsan böyle bir araba, yat vs. alamazsın, yarışma programına git, milyoner olmak istemez misin? gibi alt mesajlar vermektedir. Haberlerde her gün düzinelerce suç gören çocuk, suçu normal ve olağan bir davranış gibi görebilmektedir. Filmde kusursuz (temiz iş) işlenen suçu gören çocuk, filmdeki 'başarılı suçluyu' rol model alabilmektedir (Surette, 2011, s. 81).

Öğrenmede beğenme ve özdeşim kurma önemlidir. Suçlu ile kendisi arasında benzerlikler kuran çocuk, gördüğü davranış kalıplarını öğrenip tekrarlayabilir. Aynı şekilde, yakın çevresi suç ve suçluya olumsuz bakıyorsa, negatif özellikleriyle suçluyu kendisinden çok farklı ve ayrı gören çocuk için suç davranışı iticidir. Suçlu olmak istemez.

\section{Sebep}

Çocuğun günlük sevgi ve ilgili ihtiyacını karşılama, fayda-zarar, iyi-kötü bağlamlarında bilgilendirme, kötü davranışları belirtip onlardan sakındırma, ona iyi bir örnek oluşturma gibi olumlu, çocuğa ve istenmeyen davranışlarına kayıtsız kalma, hatta suça özendirme, teşvik etme, azmettirme gibi çeşitli seviyelerdeki olumsuz etkiler, çocuğun öğrenme süreçlerinin içinde yer almakta ve başarı, doyum veya suç olgusuyla sonuçlanmaktadır. Suç gerçekleştikten sonra telafisi güç olduğu için, doğru eğitim, aile terbiyesi ile testiyi kırmadan önce tedbir almanın önemi ortaya çıkmaktadır.

Suç niteliği taşıyan davranışların çok çeşitli nedenleri bulunmaktadır. Yaşadığı dünyayı öğrenmeye çalışan, bir takım tatmin arayışı içinde olan, mutsuzluklar yaşayan, çevresini anlayamayan ama çevresi tarafından anlaşılmayı bekleyen çocuk, öncelikle ailesine yönelmektedir. Çocuk ve ergenin psikolojisinin yakın çevresi tarafından anlaşılamaması durumunda çözümü evin dışında, medyada ve akranlarında aramaktadır. Akran çevresinin izlediği yollar, medyanın şablonları örnek ve öğretici olmaktadır. Suçu öğrenme ve suça yönelmede çocuğun yetiştiği çevre faktörünün iyi anlaşılması, çözüm üretmek için şarttır (Becker-Blease, Finkelhor, ve Turner, 2008, s. 245). 
Çocuk ve ergen psikolojisinin iyi okunması önemlidir. Bu dönemde çocuğun iç dünyasındaki kendini ispat ve heyecan arayışı, kin, nefret, güvensizlik, aşağılık kompleksi gibi duyguların doğru anlaşılması, yol gösterilmesi ve aşılması zor güçlükler karşısında ona destek olunması, tehlikeli dürtülerin ekilip beslenmesini önleyecektir. Bir insanın gelişim aşamalarının ilk evrelerinde aileye ve özellikle anneye bağımlılığı çok fazladır. Fiziksel ve zihinsel gelişim, öğrenme ve olgunlaşma ile birlikte bağımlılıklar da azalır. İnsan hayatının çeşitli aşamalarında ihtiyaçlar ve beklentiler farklılaşmaktadır. Bebeklik, çocukluk, gençlik ve orta yaş ve yaşlılık dönemlerinde yaşananlar bir sonraki aşama için belirleyici olmaktadır. Aidiyet duygusu, kimlik, kişilik, karakter, inanç ve değerler çocukluk döneminde şekillenmekte, daha sonra da pekişip kalıcılık kazanmaktadır. Çocukluk döneminin izleri asla ve asla tamamen silinememektedir.

Sosyal bir varlık olan insanın hayatiyetini sürdürebilmesi için birtakım ihtiyaçlarını karşılaması gerekir. Abraham Harold Maslow (1943), Motivasyon Teorisi veya İhtiyaçlar Hiyerarşi olarak bilinen teorisiyle, kendi içinde bir hiyerarşi oluşturan beş temel ihtiyaç belirlemiştir: Öncelikle fizyolojik ihtiyaçların karşılanması, ardından sırasıyla güvenlik ihtiyacının, ait olma, sevme-sevilme ihtiyacının, saygınlık ihtiyacının ve kendini gerçekleştirme ihtiyacının karşılanmasının doyuma ulaşım için şart olduğunu açıklamıştır (ss. 394-396). Maslow’a göre, karın doyurmadan barınmaya, para, mevki ve prestij kazanmaya kadar aşama aşama maddi ihtiyaçlar karşılandıkça bir üst basamağa, psikolojik ihtiyaçların giderilmesi aşamasına çıkılabilmektedir. Maddi ihtiyaçlar karşılansa bile, sevme ve sevilme, ilgi, şefkat görme, bir ideale inanma gibi manevi ihtiyaçlar karşılanmadı̆̆ında ya da yeterince karşılanmayıp duygusal açlık yaşandığında, toplum içinde varoluş ve tatmin aşamasına ulaşılamamakta, birey kendisini gerçekleştirememektedir. Birey iç dünyasında toplumdan uzaklaşmakta, yalnızlaşmakta, kendine ve içinde yaşadığı topluma yabancılaşmaktadır.

Her bir aşamada farklı özelliklere sahip ihtiyaçların normal ve yasal yollarla karşılanamaması halinde, sosyal ve yasal normların dışına çıkılarak ihtiyaçlar giderilmeye, 'ne pahasına olursa olsun' hedefe ulaşılmaya çalışılmakta, bu da suç niteliği taşıyan davranışların ortaya çıkmasına neden olmaktadır. 


\section{Düşünme ve hayatı anlama sistemlerinin inşası}

Toplum içinde örf, adet, gelenek, görenek, meslek etiği, toplumsal ahlak, vatan sevgisive dini değerler gibi çeşitli inançve değer sistemleriüzerine kurulur. Diğer taraftan yazılı hukuk normları bireyler tarafından içselleştirildiğinde, normalleșen normlar bireyin davranışlarını düzenlemekte, toplumda anomi ve kargaşayı, istenmeyen davranışları önlemektedir. Bu değerler sistemine sahip olmamakla birlikte ahlaki dejenerasyona uğramış çocuklarda; örf, adet, gelenek, görenek ve yasal normlara doğal olarak uyum sağlayıp ideal vatandaş olarak toplumda yer alma amaçları önemsenmemektedir. Çocukluktan itibaren çeşitli kural ve normların içselleştirilmesi, topluma karşı sorumluluk duymayı beraberinde getirmektedir. Örneğin vatan sevgisi ve görev aşkı konusunda Japon toplumu değerli bir örnek oluşturmaktadır.

\section{Hayat gayesi}

Sürmekte olduğu hayatta bir gayesi olması gerektiğinin aile tarafından çocuğa aşılanması; kendisine, ailesine, mahallesine, şehrine, ülkesine ve insanlığa faydalı olma, bunun için çalışma ve başarılı olma, kendisine ve çevresine emek verme çabalarının içine girmesi gerektiği bilinci kazandırılırsa proaktif olarak sonu suç işlemeye varabilecek istenmeyen davranışlar önceden çözülmüş olacaktır. Bir doğal afet olmadan önce, afeti önlemeye yönelik tedbir almanın maliyet, hazırlıksız yakalanılan afetten sonra ortaya çıkan mali kaybın ortalama yedide birine mal olmaktadir.

Doğru ve yeterli eğitim ve yönlendirme yapılmazsa, çocukta hedefsizlik sorunu belirecek, sorun çocukla birlikte büyüyecek, delikanlılık hatta orta yaş dönemlerine geldiğinde dahi hiç bir saygıdeğer hedefi olmayacak, hayatı ve kendi geleceğini boş verecektir. Ortaya çıan hedefsiz insanlar, toplumun üzerine ciddi bir yük oluşturacaktır. Eli boş, hiçbir amacı olmayan, bir şeyler yapmak istemeyen bir insan, ailesinden başlayarak tüm toplumun üzerinde ekonomik ve sosyal bir yük oluşturmaktadır. Faydalı insan olma çabasındakilere bakıldığında, bir şeylerin uğrunda yoruldukları, terledikleri, yerine göre uykularını, rahatlarını, hatta canlarını feda ettikleri görülür. Örneğin Çanakkale'de insanlarımız vatan uğruna canlarını feda etmişlerdir. Vatanı uğruna canını verme olgusu, sağlam bir değerler sistemi eğitiminin 
sonucudur. Uğrunda yorulacağı, terleyeceği bir şeyler olmayan insanlar, umutsuz ve mutsuz olarak yaşamak zorunda kalmaktadır.

Çocuğun iç dünyasının aileden başlayarak dışa doğru genişleyen bir sevgi ve güven çemberi ile beslenmesi, ileriye dönük bir takım ideallerin filizlenmesi için ortam oluşturmaktadır. Gelişim süreçleri boyunca bir takım yüksek ideallerin, özellikle insan ve vatan sevgisinin yeterince aşılanamadığ durumlarda, bencillik, iki yüzlülük, sahtekârlık gibi pek çok sorun ortaya çıkmakta, bunlar önlenmeye çalışılmadığında yaygınlaşmakta, toplum içinde normalleşmekte, neticede toplumsal sorunlar artmaktadır. Bu konuda da yine Japon eğitim ve kültür mekanizmalarında olduğu gibi, çocuklar insan sevgisi ve vatan sevgisi, doğa, hayvan, ağaç sevgisi ile donatıldığında; saygılı davranış nitelikleri ve erdemleriyle çekirdekten yetiştirildiğinde kuşaktan kuşağa sağlam adımlarla ilerleme görülecektir. Aksi halde dış tehditlere açık çocuk, kendi kendine çözemeyeceği ilgi ve sevgi açlı̆̆ı sorunu ile de mücadele etmek zorunda kalacaktır.

Adem Solak’ın (2009) incelediği bir kriminal vakada, ailesinden sevgi ve ilgi görmeden büyüyen bir genç kızın kendi öz annesini öldürmesini açıklarken, suçunun temelinde yatan unsur olarak yine bu sevgi ve ilgi açlı̆̆ ortaya çıkmaktadır. Kız öyküsünü şöyle özetlemektedir: "Geri dönüp baktığımda şunu görüyorum; annem, babam, bana ihtiyacım olan sevgiyi hiçbir zaman vermediler. Ben de onları sevmedim. Onların beni sevdiklerine de hiçbir zaman inanmadim..." (s. 23)

Çocukluktan itibaren maddi ve manevi olarak beslenemeyen gençlerin sorunları ilerleyen yaşlarda daha da büyümektedir. Modern toplumlarda hiç de azımsanamayacak kadar yaygın bir şekilde yer aldığı haliyle işsiz, ümitsiz ve çaresiz insanların sessiz çığllğ halde hâlâ bir düzen kuramayıp işsiz, gündelik masraflarını karşılamayan ve ne yapacağını bilemeyen bir genç erkek, "28 Years Old, No Job, No GF, No Life, Barely Able to Pay the Rent, Don't Know What to Do" başlı̆̆ıla relationshiptalk adlı internet sitesinde (Deadonarut, 2013, para. 3-8) içini dökmenin ötesinde gerçek bir çare ve umut aramaktadır. 28 yaşında olduğunu ve (hayat 
yolculuğunda) 'kaybettiğini' belirten bir genç kız (July77, 2011, para. 1-5) da, I Am in My Late 20s başlığı altında çaresizliğini dile getirmektedir.

Tüm umudunu kaybetmiş (Lost All Hope - http://lostallhope.com) adlı sitede, intihar etmeyi düşünenlere intihar yollarının 'ölüm başarım’ yüzdesi, süresi ve acısı karşılaştırmalı gösterilmektedir. $\mathrm{Bu}$ ve benzeri sitelerden çaresizlik girdabına girmiş gençlerin gidişatı şöyle şematize edilebilir: Gelir kaybı, uzun süre sabit masrafları karşılayamamak > maddi ve manevi çöküş $>$ toplumdan dışlanma ve çaresizliğe düşme $>$ destek arayışı $>$ destek ve çıkış yolu bulamama $>$ çaresizliğini kabullenme $>$ umutlarını kaybetme $>$ intihar. Neticede Bu yola girmiş kişinin nasılsa varacağı yer, ulaşacağı son belirlidir, hayat mücadelesi vermesi anlamsızdır felsefesi kabullenilmektedir. Bu bilinci kazanan genç, çaresizliğe ve umutsuzluğa teslim olmaktadır.

Öte yandan, intihar ile kendisine karşı bile acımasızca suç işleyebilecek kıvama gelmiş bir insan, başkalarına karşı suç işlemekte hiçbir sakınca görmeyecektir. Bireyselliğin ağır bastığı modern toplumlarda bu tip vakaların oranının artması, beklenmedik toplumsal çöküşlere neden olmaktadır.

\section{Sosyal roller ve rol modeller}

Bireylerin, aile başta olmak üzere, ait olduğu gruplar içinde; anne, arkadaş, öğretmen, öğrenci gibi çok çeşitli rol ve konumları vardır. Normal bir bireyden rolüne uygun davranışlar sergilemesi beklenir. Bireyin yaşına, eğitim, öğrenme ve olgunlaşma düzeyine uygun olmayan roller atfedilir ise psikolojik ve sosyolojik, hatta kriminolojik sorunlar ortaya çıkmaktadır. Anne ve babanın yaşam tarzı, kültür ve bilincine dair her ne varsa, çocuk tarafından kopyalanır, öğrenilir. Genel olarak anne, kız çocuk için; baba da erkek çocuk için rol model konumundadır. Çocuk, ebeveyninin ne söylediğinden çok, ne yaptığına bakar, onu öğrenir. Bu durumda anne ve baba çocuğu için ilk rol model konumundadır. Ona iyi örnek oluşturursa, çocuğun istendik davranışlar sergilediği görülecektir.

Çocukların öğrenme süreçlerinde akran ve arkadaşlar da belirleyicidir. Çocuklar birbirinden öğrenmeye (peeragogy) eğilimlidir. Eski zamanlardan beri bunun farkına varan atalarımızın çeşitli sözleri vardır: Üzüm üzüme 
baka baka kararır. Bana arkadaşını söyle, sana kim olduğunu söyleyeyim vb. Sağlıklı bir birey ve iyi bir vatandaştan beklenen davranış biçimleri ve erdem, ahlaki dejenerasyonla birlikte bozulmakta, suçlar yaygınlaşıp akran ve arkadaş grupları arasında kabul edilebilir hatta istendik davranışlar olarak görülmeye başlanmaktadır.

Bazı toplumlarda hırsızlık, çocuk öldürme, yamyamlık vb. davranışlar övülmeye değer bulunurken, diğerinde ayıplanır, cezalandırılır. Kız çocuklarının veya yaşlı ve sakatların öldürülmesi, sabun fabrikasına gönderilmesi anormal kabul edilmez, söylemesi de yapması da normalleşmiştir.

İlkel bir kavim olan Calliomero'larda bir baba ormandan odun ve palamut toplayıp getiremeyecek kadar güçsüz düşmüşse kendi çocukları tarafından öldürülürken, başka bir ilkel toplum olan Vater'larda yaşlanmış bir aile reisini diri diri toprağa gömmemek çocukları için utandırıcı bir leke sayılmaktadır. Eskimolarda artık işe yaramayan yaşlılar, yırtıcı hayvanların parçalamaları için doğaya bırakılırlar (Yavuzer, 1994, s. 20).

Bazı bölgelerde insanlar yaptıkları kötülüklerle saygınlık kazanırlar. Öldürdüğü insan sayısı kadar muteber sayılan kişi, üç tane leşim var diyerek övünür ve korku salar. Namus cinayetleri veya töre cinayetleri, kan davaları da yerel kültürel normlar içinde normalleşmiş, hatta bir yükümlülük olarak kabul görülmeye başlanmış, kuşaktan kuşağa aktarılmıştır. Töre ve diğer yerel normların yanlış veya yetersiz kaldığı durumlarda yüksek değerler ve erdemden beslenen başka normların eğitim ve toplumsal bilinçlendirme yoluyla topluma kazandırılması gerekmektedir.

Eski dönemlerde çocuk, terbiye mekanizmalarıyla kuşatılmış olarak yetişirdi. Komşu terbiyesi, meslek/lonca terbiyesi, (mesleğe güven ve tam teslim: eti senin kemiği benim) büyüklerin terbiyesi, öğretmen terbiyesi çok etkindi. Yeni kuşaklar bundan mahrum kalınca, onların yetiştirdiği çocuklar ise büyük oranda medya terbiyesine teslim edilmiş oldu. Öğretmen, bir çocuğun kulağını çektiğinde veya azarladığında, (çocuk tamamen hatalı olsa dahi) ailesinin çocuğu savunmak için öğretmene saldırdığı görülebilmektedir. Eğitim ve terbiye ilişkisinin sağlıklı kurulamadığı pek çok durumda doğal 
olarak çocuk suça bulaşınca ana-baba şok geçirmektedir: Hakim bey bu nasıl olur? Benim çocuğum böyle bir şey asla yapmaz, yapamaz!

\section{Formal eğitim ve informal öğrenme}

İlk yetişme ortamı olarak ailede başlayan öğrenme süreci, ilköğretim ile formal eğitime atılan ilk adımla devam etmektedir. Formal eğitim, belirli bir müfredatı olan; belirli bir ortamda, belirli periyotlarda, belirli yaş grubunun, belirli bir süre boyunca bir araya gelerek, bir eğitimcinin nezaretinde öğrenme ortamının oluşması, öğrenme düzeyinin ölçme ve değerlendirme ile tespiti neticesinde başarılı olan kişilerin sertifika veya diploma ile belgelendirilmesiyle verilen eğitimdir. İnformal öğrenme ise formal eğitimin dışında kalan tüm öğrenme ortam ve biçimlerini kapsar, süreç olarak hayat boyu öğrenme kapsamındadır. İnformal öğrenme denince akla ilk olarak medya gelmektedir, çünkü medya en etkin ve yaygın informal öğrenme aracıdır.

İnsanlar içinde yaşadıkları topluma dair bilgileri ana hatlarıyla dört kaynaktan öğrenir: aile, akran ve arkadaşlar gibi örnek aldığı insanlar; okul, kilise, sosyal gruplar ve kurumlar, kişisel tecrübeler ve medya (Surette, 2011, s. 30). Doğduğu andan itibaren anadilini öğrenmeye başlayan çocuğun informal öğrenme serüveni başlamaktadır. İnformal öğrenme, bir bireyin ailesi, sosyal çevresi veya medyadan; anadilini, kültürünü, yaşadığı yeri, toplum içindeki rolünü veya mesleğini öğrenmesidir.

Formal eğitim düzenli ordu gibidir, doğası gereği daha hantal ve yavaş işler. İnformal öğrenme ise gerilla gibidir, her zaman her yerde hazırlıksız yakalamakta ustadır, nicelik olarak küçük olmakla birlikte nitelik ve sonuç itibarıyla çok etkilidir. Formal 'okulu bırakmak' mümkündür ancak başat informal öğrenme aracı medyayı, ölmeden bırakmak mümkün değildir'. Bu yüzden, derste öğrenilenlerin medyada yanlışlanması, önemsizleştirilmesi ve çift başlılık halini önlemek üzere bu konu üzerinde ayrıntılı çalışmaların ve eylem planlarının yapılması gereklidir. Formal eğitim medyaya uymayacağına göre, medya formal eğitime uymalıdır. Öte yandan formal eğitim de informal öğrenme ortamlarına daha çok nüfuz etmelidir. Aksi halde, derste öğretmenin bir haftada yaptığını, rastgele medya içeriği beş dakikada yıkabilmektedir. 


\section{İnformal öğrenme ve suç}

Her geçen gün medyada şiddet oranı artmaktadır. İlkokulu bitirinceye kadar bir Amerikan çocuğu televizyondan ortalama 8 bin cinayet ve 100 bin şiddet eylemi görmektedir (Marsh ve Melville, 2009, s. 15). Bu kadar yoğun tekrarın mutlaka bir takım etkilerinin olması doğaldır. Medyada şiddetin yoğun bir şekilde aktarılması ve bunun neticesinde medyadan (film, polisiye roman, haber) şiddetin öğrenilmesi literatürde copycat crime $e^{3}$ terimi ile geçmektedir. Erkan Yüksel (2010), Türkiye'den kayda değer bir copycat suicide örneği anlatmaktadır: Eskişehir'de bir yerel gazete, kendisini asan gencin intihar fotoğrafını birinci sayfaya büyükçe basar. Kısa bir süre sonra bu haberi örnek alan 17 yaşında bir çocuk da aynı şekilde kendisini asar ve ayaklarının önünde bu intihar haberiyle bulunur. Çocuk haberi örnek alarak intihar etmiştir (ss. 243-245). Medyanın kanlı-canlı şiddet aktarmak ve atraksiyon yaratmaya çalışmak yerine şiddet ve 'ruhi bunalım' klişesinin dışına çıkıp sadece sonuç yerine, olayların sebeplerine de odaklanması gerekmez miydi? Bu konuda medya çalışanlarıyla da yakından ilgilenmek ve onları medyada şiddetin bireyler üzerindeki potansiyel etkileri konusunda eğitmek gerekmektedir.

Ekranda görülen başarılı insanlar, ünlüler ve diğer medya profesyonelleri, çocuklar için başat rol model olmakta, başlangıçtaki ana-baba rol modelliği, medyayla fazlasıyla dışarıya taşmaktadır. Çocuk medya ve diğer sosyal çevrenin eline bırakıldığında suç işleme eğilimi artmaktadır. Elbette medya çocuğa doğrudan suç işlettirmemektedir ancak suç ile sonuçlanacak zemini hazırlamakta, suça kapı aralamaktadır (Surette, 2011, ss. 67-81). Özellikle ergenlik çağında ve gelişimin dorukta olduğu dönemlerden fiziksel olgunlaşmaya kadar olan dönemde medyadakilerin davranış kalıpları öğrenilip taklit edilmektedir.

Dijital çağda informal öğrenme ortamları internet ve bilgi teknolojileriyle birlikte genişlemiştir (Quinton, 2006, ss. 547-548). Bu durumda, sadece örgün

\footnotetext{
${ }^{3}$ Bu metinde orijinal terimlerin Türkçe açıklamasını yapmak yerine, doğrudan metin içinde kullanılmasının birkaç nedeni vardır: Öncelikle bu makalenin yazıldığı sıralarda henüz sözlüklere bu copycat crime teriminin Türkçe karşılığı girmemişti, diğer neden; hem medya, hem kriminoloji, hem psikoloji gibi farklı disiplinlerle ilgili bu tip terimlerin görünürlüğünü sağlamak, bir başka neden; müteakip araştırmacıların adeta alan adı gibi, böylesine kilit bir anahtar kelimeyi kullanarak, devasa bilgi birikimine pratik bir şekilde ulaşmalarına yardımcı olmak. Bu terime Türkçe karşılık olarak, medyadan suç taklidi veya kısaca suç taklidi diyebiliriz. Aynı şekilde copycat suicide için de medyadan intihar taklidi denebilir.
} 
eğitimin yeterli olmadığ aktif katılımı ve iş birliği ile gerçekleştirilecek informal öğrenme kanallarının da çocuğun olumlu gelişimine katkı sağlayacak şekilde organize edilmesinin gerekli olduğu ortaya çıkmaktadır.

Eğitimsiz veya doğru eğitimi alamamış insanların daha kolay suça karışması ile ilgili bir Alman atasözü vardır: Ya eğit, ya katlan. Bu söz, eğitimsizlik ile onun olumsuz sonuçları arasında doğrudan bir bağ kurmaktadır. Çocuk ihtiyacı olanı aile ve okuldan alamazsa oluşan boşluğu medya fazlasıyla doldurmaktadır. Çocuklar karıştıkları suç ile medyatize olurlarsa, (teşhir) 'suçlu' sıfatıyla toplumun dikkatini çekmekte ve genellikle insanlar bu sonucun olası nedenleriyle ilgili kişisel görüşlerini dile getirmekle yetinmektedir.

\section{Sonuç: Suç}

Toplum içinde bir davranışın suç sayılabilmesi için o davranışın yasal ve sosyal normları ihlal etmesi, suçun maddi ve manevi unsurlarının gerçekleşmiş olması gerekmektedir. Tipkı toplum tarafından olumlanan, takdir toplayan veya çeşitli şekillerde ödüllendirilen davranış ve eylemlerde olduğu gibi, suç işleme eylemi de genellikle öğrenme süreçlerinin neticesinde ortaya çıkmaktadır. Ancak, okullarda verilen formal eğitim ile istenmeyen davranışlar önlenmeye çalışılır iken, okul dışındaki aile, sosyal çevre, akran ve medya gibi informal öğrenme kanalları ile istenmeyen davranışların öğrenildiği, normalleştiği de görülmektedir.

Çocuklar suç konusunda kimi zaman etken, genellikle de edilgen, yani mağdur konumundadır. Çocuklar çok çeşitli şiddet türüne maruz kalmakta, suça itilmekte ve küçük yaşta suç olgusuyla tanışmaktadır. The United Nations Children's Fund [UNICEF] (2007) tarafından çocuklara dönük şiddet türleri şöyle belirlenmiştir (ss. 60-61): Akranlardan kaynaklanan şiddet, cinsel şiddet veya istismar, çete şiddeti, insan ticareti, siber tehditler, sığınmacılara uygulanan şiddet, görevlilerden kaynaklanan şiddet. Buna medya şiddetini de eklemek gerekir. Filmlerde binlerce kez silah ve öldürme gören, gerçek hayatta da öldürme haberleri alan çocuk, şiddeti normal görmeye, kabullenmeye ve hatta sergilemeye hazırlanır. 
TÜİK çevrimiçi veri tabanından (Merkezi Dağıtım Sistemi [MEDAS], 2015) elde edilen, 2009 ve 2014 ylllarında Türkiye geneli verilerine göre; hırsızlık, sahtecilik, bilişim suçları, cinsel suçlar gibi suçlar ortalama ikiye katlanmıştır. Bazı suç türlerinde aşırı dengesiz bir artış görülmüştür. Örneğin 'kötü muamele' suçunun sayısı bu dönemde 93’ten 1417’ye çıkmıştır.

Beş yıl gibi kısa bir sürede bu kadar fazla suç eylemi nereden öğrenilmiş ve denenmiştir? İçeriden aile ve sosyal çevre kendi bilmediği, keşfetmediği, yaşamadığı, bilişim suçları gibi yeni ve teknolojik suçları çocuğa örnek olup öğretemeyeceğine göre; bu suç türleri merkez medya, dijital ve sosyal medya veya başka yollarla topluma 'dışarıdan' girmiş olmalıdır. Örneğin tehdit suçu isnat edilen çocuk sayısı 2009 yılında 2111 iken, 2014 yılında 4391'dir. Bu artış ile; çocuk için en erişilebilir medya olan televizyonda 'tehdit' içeren dizi, film ve benzeri örnek ve öğrenme aracı potansiyeline sahip olan programlar arasındaki korelasyon nedir? Bu ve benzeri konularda daha detaylı araştırmaların yapılması ve yayıncıların da içerik üretimi ve içerik seçimi konusunda bilgilendirme ve bilinçlendirilmeleri gereklidir.

Toplum içinde suç yokluk ile ilişkilendirilir, suç işleyen çocukların çoğunlukla sosyo-ekonomik düzeyi düşük, yoksul ailelerden geldiği görülmektedir (Yavuzer, 1994, s. 34). Ancak, varlıklı insanlarda da benzer veya çok farklı suçlar görülmektedir. Bu durumda yokluk, sadece para ve maddi imkânlardan yoksun kalmak değil, ilgi ve sevgiden yoksun kalmayı da içerir. Çocuk gelişiminde sadece fiziksel ihtiyaçların karşılanması yeterli değildir. Dozajı doğru ayarlanmış sevgi ihtiyacının da tam olarak karşılanması kritik öneme sahiptir. Çünkü çocuk ana-baba sevgisine muhtaçtır. Bu sevgi sayesinde kendisine ve yaşadığ Yavuzere (1996) göre çocuk, "sevildiğini hissetmeden yaşayamaz. Çocuk, anababa sevgisinin kendi şahsına yönelik olmasını ister. Başarılı olduğu için, iyi not aldığı için değil, şartsız olarak gerçekten sevginin kanıtlanmasına ihtiyacı vardır. Sevildiğinden emin olan çocuk, sevgisini beklediği kişileri azaba sokarak inatçı bir biçimde hoşa gitmeyecek davranışlar içine girmeye gerek görmez" (ss. 34-35). Görüldüğü gibi sevgi ve ilgi anahtar bir role sahiptir. 


\section{Sonuç ve Öneriler}

Nedensellik bağı üzerine kurulu olarak sorun, sebep, sonuç, çözüm uzamında yapılan bu incelemede, birbiriyle uzak gibi olan faktörlerin aslında nasıl iç içe geçmiş olduğu ortaya çıkmıştır. Doğal kaynaklar sadece su, toprak, maden gibi doğada hazır bulunanlar değildir. İnsan yetenek ve becerilerinden oluşan insan kaynakları en değerli doğal kaynaklardandır. Çünkü diğer kaynakları doğru ve etkin kullanacak olan insandır. İnsanın yetenek ve becerilerini ortaya çıkarıp, çalışmaya motive edip ahlâk ve erdemle donatıp topluma faydalı hale getirmek en önemli sorumluluktur.

Aristo demiştir ki;

'Pratik bilgelik', 'ahlaki irade ve ahlaki becerinin birleşimidir.' Bilge insan, bu ahlaki becerileri doğru amaçlar için nasıl kullanacağını bilir: Başkalarına fayda için; kandırmak için değil. Bilge doğulmaz; bilge olunur. Bilgelik, deneyime (öğrenmeye) dayanır; ama doğru deneyimlerin yaşanması; deneyip yanılıp hatalarından ders çıkarmak için firsat verilmesi gerekir (aktaran Schwartz, 2009: 03' 33”)

\section{Sorumluluk bilincinin inşası}

Geleceğin büyükleri olacak çocukların milli çıkarlar ve ulusal kültürel değerler zemininde yetiştirilmesi ve kendisinden başlayıp tüm insanlığa karşı sorumluluk bilinci içinde yetiştirilmesi çok önemlidir. Irk, din, kültür, fiziksel özellikler gibi hassas konularda olumsuz sıfatlar, (nefret söylemi) vurdulu, kırdılı, küfürlü sözcükler çocuğun yanında çok kullanılırsa, çocuğun düşünsel dünyası ve sözcük dağarcığı olumsuz ifadelerle biçimlenecektir. Kötülük eken, iyilik biçemez. Çocukları iyilikle, sevgiyle yetiştirmek, hem karnını, hem zihnini doğru doyurmak çok önemlidir.

\section{Ana baba eğitimi}

Çocuk nasıl yetiştirilir? sorusuna tam ve doğru cevap verebilmesi için önce ebeveyni eğitmek gerekir. Ebeveyni kişilerarası iletişim, psikoloji, sosyoloji, kültür ve ekonomi konularında eğittikten sonra istendik sonuçların elde edilmesi beklenebilir. Ana-baba eğitimli değil, çocuk yetiştirme konusunda 
da yeterli bilgiye sahip değilse, çocuğunu iyi yetiştirmek yerine ona eziyet edebilir, zarar verebilir.

Böyle bir ailede yetişip kaçınılmaz sonuç olarak suça bulaşmış bir çocuk; hükümlü-tutuklu iyileştirme programlarında israrla: Aileler çocuklarını tehlikelerden korumalıdır. diyen eğitimciye şu soruyu soruyor: Ya ailelerin tehlikelerinden çocukları kim koruyacak (Solak, 2009, s. 82)? Bu durumda, proaktif bir önlem olarak, aile 'tehlikeli ortam' haline gelmeden önce anne ve baba adayları iyi eğitilmeli ve çocuklarını doğru eğitecek bilgi ve birikimle donatılmalıdır. Ya medyanın tehlikelerinden çocukları kim koruyacak? diye sorulacak olursa cevap, 'medya okuryazarlığı eğitimi vermek ve önce ebeveynlere, sonra çocuklara sağlam bir medya bilinci kazandırmak' olacaktır. Ana hatlarıyla belirtmek gerekirse, ailelerin eğitimi, medya profesyonellerinin eğitimi ve denetlenmesi, aile-okul iş birliği ve ebeveyn eğitimi başlıkları altında sonuç odaklı bir takım çalışmaların yapılmasının önemi ortaya çıkmaktadır.

The Walking Dead, Lost, Prison Break gibi günden güne sayıları artan, şiddet ve suçu normalleştiren, duyarsızlaşmaya neden olan, çocukların psikolojik yapılarına zarar veren ${ }^{4}$ dizi-oyunların kimi yararlarından bahsedenler bile ortaya çıkmaktadır. Örneğin Walking Dead'den öğrendiğimiz 7 hayat dersi başlıklı bir internet gazetesi yazısında (Alkaya, 2014, para. 2-14), (doğuştan suçlu) vahşi kapitalizm ve doğal seleksiyon karışımı yaklaşımla, bu serinin adeta ibretlik ve ders çıkarılacak nitelikte olduğuna göndermede bulunulmaktadır. Bu tip durumlar şöyle özetlenebilir: Önce dozerle ez, sonra eline bir çiçek ver! $\mathrm{Bu}$ tip yapımların alanda uzman ekiplerce denetlenip erişiminin kontrol altına alınması, ebeveynlerin de bu konuda bilinçlendirilmesi gerekmektedir. Çocuklar dijital mecralarda başıboş bırakılırsa, onlara psikolojik ve fizyolojik tehditlerin sahip çıkacağı açıtırı.

\section{Sağlıklı aile ortamı}

Genetik yatkınlık nedeniyle psikolojik sorunları doğuştan getiren [born criminal] bireyler (nadir olarak) bulunmasına rağmen, suç eğiliminin aile

\footnotetext{
${ }^{4}$ Diziyi seyreden çocuklardan görüştüğüm birçoğu, dizinin gece rüyalarına girdiğini, kabus gördükleri için artık izlememeye karar verdiklerini, diziden nefret ettiklerini ama buna rağmen kendilerini alıkoyamayıp diziye devam ettiklerini -assında bağımlısı oldukların- belirttiler.
} 
eğitimiyle azaltılabileceği veya arttırılabileceği bilinmektedir. Suçlu çocuk yoktur, suça itilmiş çocuk vardır, ifadesinde ailenin durumunun çocuğun gelişiminde çok büyük önemi olduğu, ebeveynin çocuğa nasıl örnek olup, nasıl eğittiği ve yönlendirdiğinin çocuk için en belirleyici unsurlar olduğu ortaya çıkmaktadır (Yavuzer, 1994, s. 149).

Suça karışan çocukların aile ilgi ve takibinden uzak, yalnız, dış dünyanın istismarına açık olarak karar verdikleri görülmektedir. Örneğin terör örgütleri sosyal medya üzerinden çocuk ve gençleri tuzaklarına düşürmekte, örgütleyip suça bulaştırmaktadır. İnternet kafeler, ideolojik ortamlar, mahalle çeteleri, köşeciler, çocukların zihnindeki örgüt yapılarını besleyen, güçlendiren çöplüklerdir. Çocuklar bu çevrelerin insafina terk edilmemeli, okul-aile iş birliği içinde izlenip, korunup kollanmalıdır (Solak, 2009, s. 147).

Çocuğun ilgisiz kalması ve başkalarının insafına terk edilmesi büyük bir sorun iken, aşırı ilgilenme, üzerine düşme de bir başka sorundur. Aşırı ilgi çocuğun şımarması ve hazırcılığa yönelmesine sebep olacağından; sevgi, ilgi ve özgüven dengesinin doğru kurulması çok önemlidir. Aileler sorumluluklarının sadece kendi çocukları ile sınırlı olduğunu düşünmemeli, başkalarının çocuklarına, yetiştirme yurtlarındaki çocuklara karşı da sorumluluk taşımalı, sorumluluğu sadece devlete yüklememelidir. Yardımlaşma, dayanışma, sevgi ve saygı üzerine kurulu insani ilişkilerle bireylerin büyük bir aile içinde yaşadıklarını hissettikleri toplumlarda mutluluk ve refah düzeyi en yüksek seviyededir. Ailelerin toplumun dışlanan kesimleri ile ilgilenmelerini, onları yalnızlığa itmemelerini sağlamak üzere eğitim kampanyaları, sosyal projeler düzenlemek, sorunlara etkili çözümler sunacaktır.

\section{Başıboș bırakmama}

Ahmad ve Fisher'in (2006) aktardığ 1 bir araştırmaya göre, büyük kentlerin yuttuğu, otorite ve kontrol mekanizmalarının zayıf olduğu kim kime, dum duma kent yaşamında çocukların ödevini yapmama, öğretmenini saymama, okuldan kaçma ve kavga etme düzeyleri, kırsal kesimlerde yaşayan emsalleriyle karşılaştırılmış ve büyük kentlerin istenmeyen davranışlar konusunda çok daha 'sorunlu' ve 'tuzaklarla dolu' olduğu bulunmuştur. Kırsal kesim çocuğu ise, tıpkı birbiriyle bağlantılı ve birbirini 'gören' büyük bir aile gibi hemen 
herkesin birbirini tanıdığı ortamda daha sorumlu davranışlar sergilemektedir (ss. 511-512). Çocuk yetiştirmek başlı başına bir ihtisastır. Yetişkinler ana-baba olmadan önce çocuk yetiştirme sanatında; teknik, estetik, ahlaki, psikolojik, sosyolojik zeminlerde tam olarak yetiştirilmelidir.

\section{Eğitimci davranıșı}

Bir entelektüel ve bilge kişi olarak öğretmenin doğrudan ceza verme, akranlarının arasında rencide etme, aşağılama yollarından kaçınıp ödülceza mekanizmalarında; ödüllendirme, teşvik etme lehine yönelmesi, çocuğu bilgilendirme ve bilinçlendirme yollarını tercih etmesi gerekmektedir. Öğretmen, öğrencilerin başarısızlıkları ve istenmeyen davranışları karşısında daha fazla sorumluluk hissetmeli, öğrencilerin olumlu durumlarını bir mutluluk kaynağına dönüştürmelidir.

Uluslararası yasalar başta olmak üzere, modern hukuk ve toplumsal yansıması çocuğa kaldırabileceğinden fazla özgürlük tanırken, öğretmenin çocuğu tehlikelere karşı kısıtlaması güçtür. Ancak tehlikeli özgürlükler konusunda çocuğu bilgilendirmek de önemli bir erdemdir. Psikolog Barry Schwartz’a göre batılı toplumların merkezi inancı olan, her şeyi 'bireyselleştirme' ve 'seçme' üzerine kuran seçme özgürlüğü şudur: 'Seçmek (seçme illüzyonu; neyi, neden seçmesini gerektiğini bilemeyen, kafası karışık) bizi daha özgür değil aksine daha felçli yapar; daha mutlu değil, daha tatminsiz oluruz (2005, 0' 31")"

Gündelik hayat ve medya teknolojileri karmaşıklaştıkça, sorunlar da çok karmaşık hale gelmeye başlamıştır. Sorun çözümünde bireysel çabaların yetersiz kalması normaldir. Suçun kök nedenleri iyi araştırılmalıdır. Asıl nedeni bilinmeyen bir sorunun çözümü de olamaz. Çocuklarda suç olgusu, eğitim başta olmak üzere, ilgili faaliyet alanlarının uyum ve işbirliği halindeki çalışmalarıyla uzun vadeli çözümlerin üretilip uygulamaya konulabileceği bir sorundur. Bu yüzden, münferit çabalar yerine, otoritenin organizatörlüğü ile bilgi birikimi ve tecrübeleriyle farklı uzmanlık alanlarını ve sektörleri bir araya getiren ve takım çalışmasıyla ortak akıl üretecek sinerjinin oluşturulması gerekmektedir. 
İyilik, kötülük, kolaylık ve zorluklarıyla hayat başlı başına büyük bir sınavsa, hayattaki icraatlarından sorumlu tutmak için, insanları önce eğitmek, bilgilendirmek gerekir. Bilgilendirilmemiş olan bir kişi, bilmediği bir konuda sınav yapılamaz, her zaman doğru olanı yapması da beklenemez. Zararlı ve kötü eylemlerde bulunmaması için her bir bireyin başına bir bekçi dikmek mümkün değildir. Ancak eğitim yoluyla insanların vicdanına bir bekçi dikildiğinde, suça dönüşen veya dönüşmemiş çok çeşitli kötülüklerin daha kolay ve etkin bir şekilde önlenmesi sağlanabilir. 


\section{Kaynakça}

Ahmad, W., ve Fisher D.L. (2006). School climate in Indonesian junior secondary schools. D.L. Fisher ve M. S. Khine (Ed), Contemporary approaches to research on learning environments worldviews, (ss. 497-516). Singapore: World Scientific Publishing.

Alkaya, O. V. (02.12.2014). 5 Sezonda Walking Dead’den öğrendiğimiz 7 hayat dersi. Erişim Tarihi: 05. 12. 2015. www.radikal.com.tr/radikalist/5-sezonda-walking-deaddenogrendigimiz-7-hayat-dersi-1243333/

Becker-Blease, K. A., Finkelhor, D., ve Turner, H. (2008). Media exposure predicts children's reactions to crime and terrorism. Journal of Trauma \& Dissociation, 9(2), ss. 225-248.

Bilici, İ.E. (2014). Medya okuryazarlı̆̆ ve eğitimi. Ankara: Nobel.

Bushman, B. J., Gollwitzer, M., ve Cruz, C. (2015). There is broad consensus: Media researchers agree that violent media increase aggression in children, and pediatricians and parents concur. Psychology of Popular Media Culture, 4(3), ss. 200-214. DOI: $10.1037 / \mathrm{ppm} 0000046$

Callanan, V. (2005). Feeding the fear of crime: crime-related media and support for three strikes. New York: LFB Scholarly Publishing.

Deadonarut. (2013). 28 years old, no job, no gf, no life, barely able to pay the rent, don't know what to do. Erişim tarihi: 24.10.2015, www.relationshiptalk.net/28-years-old-nojob-no-gf-no-life-barely-able-to-pay-the-rent-dont-know-what-to-do.-31808831. html.

Ercan, R. (2014). Gündelik yaşamda işlevsel olarak kullanılan Türk atasözlerinde çocuk imgeleri. Mustafa Kemal Üniversitesi Sosyal Bilimler Enstitüsü Dergisi, 11(27), ss. 1531 .

Gültekin, F. (2013). Eğitimde ödül-ceza dengesi. Erişim tarihi: 01.01.2016, http://www. aileakademisi.org/arastirma/egitimde-oedul-ceza-dengesi-ceza-korkusundanoedul-bagimliligina.

Hibberd, J. (2012). 'Walking Dead' premiere gets fall's biggest rating Erişim tarihi: 20/12/2015, http://insidetv.ew.com/2012/10/15/walking-dead-season-3-premiereratings. 
İçli, T. G. (2009). Çocuk suç ve sokak sokakta yaşayan suç işleyen ve suça maruz kalan çocuklar (Genel Yayın No:142). Ankara: Başbakanlık Aile ve Sosyal Araştırmalar Genel Müdürlüğü.

July77 [Nick Name]. (2011). I am in my late 20s. Erişim tarihi: 01.01.2016, www. experienceproject.com/stories/am-in-my-late-20s/1337951.

Marsh, I., ve Melville, G. (2009). Crime, justice and the media. London and New York: Routledge.

Maslow, A. H. (1943). A theory of human motivation. Psychological Review, 50(4), ss. 370-396.

Quinton, S. (2006). A brief critique on the future of learning (Assessing the potential for research). D. Fisher ve M.S. Khine, (Ed.), Contemporary approaches to research on learning environments: Worldviews (ss. 543-578). Singapore: World Scientific Publishing.

Schwartz, B. (2005). The paradox of choice. Erişim tarihi: 13.11.2015, https://www.ted. com/talks/barry_schwartz_on_the_paradox_of_choice

Schwartz, B. (2009). Our loss of wisdom. Erişim tarihi: 12.11.2015, https://www.ted.com/ talks/barry_schwartz_on_our_loss_of_wisdom?language=en.

Solak, A. (2009). Şiddeti anlamak. Ankara: Hegem.

Surette, R. (2011). Media, crime and criminal justice images, realities, and policies. Wadsworth: Wadsworth Cengage Learning.

Şirin, M. R. (2011). Şiddet, televizyon ve çocuk dostu medya. M. R. Şirin (Ed.), 1. Türkiye Çocuk Hakları Kongresi Bildiri Kitabı (ss.163-182). İstanbul: Çocuk Vakfı Yayınları.

The United Nations Children's Fund [UNICEF]. (2007). Çocuklara yönelik şiddetin ortadan kaldırılması (Parlamenterler İçin Elkitabı No:13). Fransa: IPU Headquarters.

Türkiye İstatistik Kurumu [TÜİK]. (2014). Türkiye İstatistik Kurumu istatistiklerle çocuk 2014 (Yayın No: 4372). Ankara: Türkiye İstatistik Kurumu Matbaası.

Türkiye İstatistik Kurumu Merkezi Dağıtım Sistemi [MEDAS] çevrimiçi veri tabanı. Erişim tarihi: 19.12.2015, www.tuik.gov.tr/PreTabloArama.do?metod=search. 
Yavuzer, H. (1994). Çocuk ve suç (7. baskı). İstanbul: Remzi Kitabevi.

Yavuzer, H. (1996). Ana-baba ve çocuk, ailede çocuk eğitimi (9. baskı). İstanbul: Remzi Kitabevi.

Yüksel, E. (2010). Medya ve habercilik. Konya: Çizgi. 